\title{
PENGARUH KARAKTERISTIK LINGKUNGAN TERHADAP MAKROZOOBENTOS DI KAWASAN REBOISASI MANGROVE KEPULAUAN SERIBU, INDONESIA
}

\section{Syahrial ${ }^{1}$, Rika Anggraini ${ }^{2}$, Agus Putra Abdul Samad ${ }^{3}$, Nur Ikhsan ${ }^{4}$, Dandi Saleky ${ }^{5}$,La Ode Abdul Fajar Hasidu ${ }^{6}$}

${ }^{1}$ Program Studi IImu Kelautan, Universitas Malikussaleh, Aceh, Indonesia ${ }^{2}$ Jurusan IImu Kelautan, Universitas Maritim Raja Ali Haji, Kepulauan Riau, Indonesia

${ }^{3}$ Program Studi Budidaya Perairan, Universitas Samudra, Aceh, Indonesia ${ }^{4}$ Akademi Komunitas Kelautan dan Perikanan Wakatobi,

Sulawesi Tenggara, Indonesia

${ }^{5}$ Jurusan Manajemen Sumberdaya Perairan, Universitas Musamus, Papua, Indonesia

${ }^{6}$ Program Studi IImu Kelautan, Universitas Sembilanbelas November

Kolaka, Sulawesi Tenggara, Indonesia

E-mail: syahrial.marine@unimal.ac.id

Received June 2020, Accepted September 2020

\begin{abstract}
ABSTRAK
Fauna bentik (makrozoobentos) telah dianggap sebagai salah satu kriteria untuk menilai keberhasilan program restorasi mangrove. Kajian korelasi karakteristik lingkungan terhadap makrozoobentos di kawasan reboisasi mangrove Kepulauan Seribu telah dilakukan pada bulan Maret 2014. Hal ini bertujuan untuk mengetahui pengaruh yang diakibatkan oleh karakteristik lingkungan (parameter fisika kimia perairan) terhadap kepadatan makrozoobentosnya. Data biota makrozoobentos di kawasan reboisasi mangrove Kepulauan seribu dikumpulkan dengan membuat transek garis dan plot yang ditarik dari titik acuan (tegakan mangrove terluar) dan tegak lurus garis pantai sampai ke daratan, dimana pengamatan dilakukan di tiga stasiun (pulau). Sebanyak 6 famili dan 6 spesies makrozoobentos telah ditemukan di kawasan reboisasi mangrove Kepulauan Seribu. Komposisi dan kepadatan spesies tertingginya adalah Littoraria scabra. Karakteristik lingkungan yang diukur tidak begitu berbeda antar stasiun serta juga tidak melebihi ambang batas baku mutu. Semakin rendah konsentrasi salinitas dan DO, maka kepadatan makrozoobentosnya semakin tinggi, sedangkan semakin tinggi konsentrasi $\mathrm{pH}$ perairan, maka kepadatan makrozoobentosnya semakin menurun. Kemudian parameter suhu dengan kepadatan makrozoobentos tidak memiliki pengaruh.
\end{abstract}

Kata Kunci : Pengaruh, Karakteristik Lingkungan, Makrozoobentos, Mangrove, Reboisasi, Kepulauan Seribu 


\section{ABSTRACT}

THE EFFECT OF ENVIRONMENTAL CHARACTERISTICS OF MAKROZOOBENTOS IN MANGROVE REFORESTATION AREA OF SERIBU ISLANDS, INDONESIA. Benthic fauna (macrozoobenthos) has been considered as one of the criteria for assessing the success of a mangrove restoration program. A correlation study of environmental characteristics of macrozoobenthos in the Seribu Islands mangrove reforestation area was carried out in March 2014. It aims to determine the effect caused by environmental characteristics (water physical-chemical parameters) on its macrozoobenthos density. Data of macrozoobenthos biota in the Seribu Islands mangrove reforestation area were collected by making line transects and plots drawn from the reference point (outermost mangrove stands) and perpendicular to the coastline to the mainland, where observations were made at three stations (islands). Six families and six macrozoobenthos species have been found in the Seribu Islands mangrove reforestation area. The composition and density of the highest species were Littoraria scabra. The measured environmental characteristics were not very different between stations and also did not exceed the quality standard threshold. The lower the salinity and DO concentration, the higher the density of macrozoobenthos, while the higher the concentration of water $\mathrm{pH}$, the lower the density of macrozoobenthos. Then the temperature parameters with macrozoobenthos density had no effect.

Keywords : Influence, Environmental Characteristics, Macrozoobenthos, Mangrove, Reforestation, Seribu Islands

\section{PENDAHULUAN}

FAO (2007) menyatakan bahwa kerusakan mangrove bukanlah masalah baru dan sudah mulai terjadi dari $0.7 \%$ hingga $2.0 \%$ pertahunnya, kemudian Mayaux et al., (2005) menyatakan bahwa kehilangan hutan mangrove global selama periode $1980-2005$ diperkirakan > 3 juta ha ${ }^{10}$ dan tingkat degradasinya mencapai $1 \%$ per tahun dari 1990 - 2000 (dua kali lipat dari hutan hujan terestrial). Selanjutnya Wolanski et al., (2000) menyatakan bahwa selama 20 tahun terakhir, beberapa negara Asia telah mengalami kerusakan mangrove 50 $-80 \%$. Hal ini akibat dari konversi mangrove menjadi lahan pertanian (Giri et al., 2008), kemudian juga disebabkan oleh akuakultur/budidaya dan penggunaan lahan perkotaan (Friess dan Webb, 2013), urbanisasi maupun industrialisasi (Bosire et al., 2008). Sementara aktivitas alami yang juga sebagai penggerak rusaknya hutan mangrove adalah suksesi hutan, dinamika hidrologi serta cuaca ekstrim, baik itu disebabkan oleh angin topan maupun kenaikan permukaan air laut (Alongi, 2008; Suzuki et al., 2011).

Aboudha dan Kairo (2001) menyatakan bahwa kehilangan/kerusakan mangrove yang terus berlanjut akan menyebabkan penurunan sektor 
perikanan maupun barang dan jasa lainnya, kemudian Donato et al., (2011) menambahkan bahwa deforestasi mangrove dapat menyumbang sekitar 10\% dari emisi global. Sementara Siikamaki et al., (2012) menyatakan bahwa deforestasi akan mengurangi penyimpanan biomassa karbon maupun keanekaragaman hayati mangrove, sehingga akan berdampak terhadap kepunahan $16 \%$ spesies mangrove global (Polidoro et al., 2010). Selain itu, berkurangnya kawasan mangrove di wilayah pesisir juga akan membuat warga sekitarnya menderita saat terjadi air pasang karena banjir (Zainuri et al., 2017) dan akan menambah tingkat kematian per desa yang berada pada jarak $10 \mathrm{~km}$ dari pantai jikalau mangrovenya telah tiada (Das dan Vincent, 2009).

Chong (2007) menyatakan bahwa hutan mangrove berfungsi sebagai tempat penghasil spesies nekton yang komersial; penyuplai nutrien (Alongi, 2013); penyedia bahan bakar, makanan maupun bahan bangunan (Bandaranayake, 1998); melindungi dari badai (Sheng dan Zou, 2017); penyimpan karbon (Donato et al., 2011; Kelleway et al., 2016, Yando et al., 2016); perangkap sedimen (Kamal et al., 2017); penyedia layanan untuk perikanan (Benzeev et al., 2017; Goecke dan Carstenn, 2017) hingga bermanfaat bagi pertumbuhan lamun dan terumbu karang sekitarnya (Gillis et al., 2017).

Mengingat ancaman terhadap kelangsungan hidup mangrove yang terus menerus terjadi, sedangkan peran mangrove juga begitu produktif di wilayah pesisir, maka menjadi alasan yang kuat untuk memulihkannya kembali (Pagliosa et al., 2016). Menurut Field (1999) restorasi mangrove telah dilakukan di seluruh dunia, dengan tujuan untuk memulihkan struktur ekologi dan fungsi hutan mangrovenya (Field, 1999; Barbier, 2006) dan kajian-kajian yang berkaitan dengan rehabilitasi mangrove juga telah banyak dilakukan (Elliott et al., 2016; Kodikara et al., 2017). Begitu juga dengan kajian biota asosiasinya (Macintosh et al., 2002; Ellison, 2008; Salmo et al., 2017), sehingga diperoleh suatu kesimpulan bahwa komunitas biota asosiasi atau makrozoobentos dapat digunakan sebagai bioindikator dalam mengukur keberhasilan program rehabilitasi mangrove (Macintosh et al., 2002; Bosire et al., 2008; Ellison, 2008; Pagliosa et al., 2016). Namun, informasi tentang pengaruh karakteristik lingkungan terhadap fauna makrozoobentos di kawasan reboisasi mangrove di Kepulauan Seribu masih sangat terbatas, sehingga diperlukan suatu kajian tentang hal tersebut dengan tujuan untuk mengetahui pengaruh yang diakibatkan oleh karakteristik lingkungan (parameter fisika kimia perairan) terhadap kepadatan makrozoobentos di kawasan reboisasi mangrove Kepulauan Seribu.

\section{MATERI DAN METODE}

\section{Waktu dan Tempat Penelitian}

Kajian dilaksanakan pada bulan Maret 2014 di kawasan reboisasi mangrove Kabupaten Kepulauan Seribu Provinsi Daerah Khusus Ibukota 
(DKI) Jakarta. Stasiun 1 berada di Pulau Pramuka, Stasiun 2 di Pulau Panggang dan Stasiun 3 di Pulau Karya (Gambar 1).

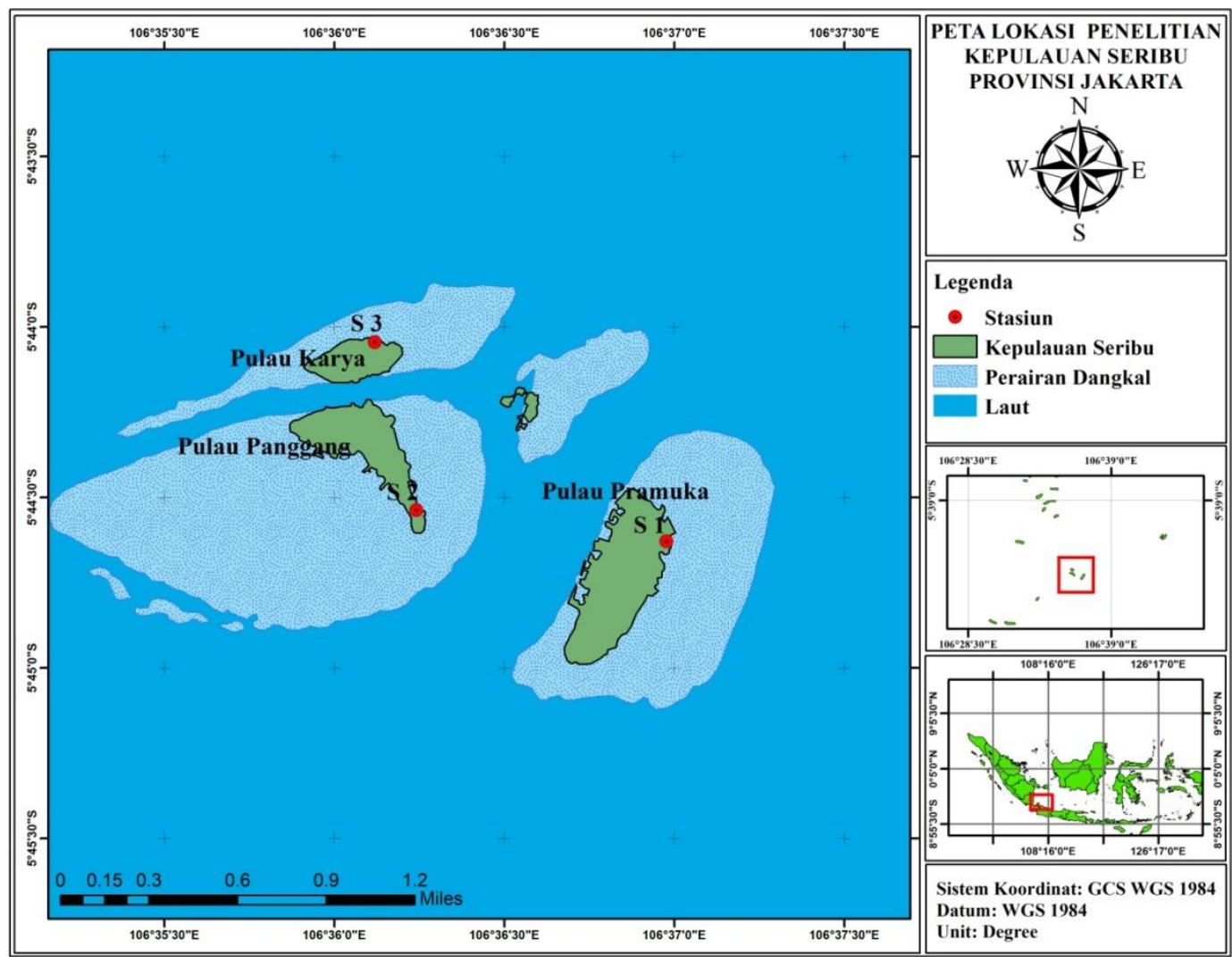

Gambar 1. Peta lokasi penelitian

\section{Pengumpulan Data Karakteristik Lingkungan}

Pengukuran karakteristik lingkungan dilakukan dengan cara in-situ yaitu mengambil contoh air pada masing-masing stasiun pengamatan, dimana parameter karakteristik lingkungan yang diukur meliputi suhu perairan, $\mathrm{pH}$ dan salinitas dengan menggunakan water quality meter. Sementara parameter oksigen terlarut (DO) menggunakan data sekunder.

\section{Pengumpulan Data Makrozoobentos}

Data makrozoobentos di kawasan reboisasi mangrove Kepulauan seribu dikumpulkan dengan membuat transek garis dan plot yang ditarik dari titik acuan (tegakan mangrove terluar) dan tegak lurus garis pantai sampai ke daratan, kemudian transek garis tersebut dibuat petak-petak contoh (plot) dengan ukuran $10 \times 10 \mathrm{~m}$ dan di dalam ukuran $10 \times 10 \mathrm{~m}$ tersebut dibuat plot-plot kecil (sub plot) yang berukuran $1 \times 1 \mathrm{~m}$ (Ernanto et al., 2010) sebanyak 5 plot, sehingga jumlah sub plot keseluruhannya adalah 45. 


\section{Analisis Kepadatan Makrozoobentos}

Analisis kepadatan makrozoobentos di kawasan reboisasi mangrove Kepulauan Seribu dilakukan berdasarkan Odum (1971), Southwood (1978), Brower dan Zar (1984) serta Krebs (1989).

\section{Analisis Pengaruh Karakteristik Lingkungan Terhadap Makrozoobentos}

Untuk mengevaluasi pengaruh karakteristik lingkungan terhadap makrozoobentos di kawasan reboisasi mangrove Kepulauan Seribu dilakukan menggunakan analisis regresi linier sederhana (Hasby et al., 2014; Mushthofa et al., 2014; Pamuji et al., 2015; Wahyuningrum et al., 2016; Mustofa, 2018).

\section{HASIL DAN PEMBAHASAN}

\section{Distribusi dan Komposisi Makrozoobentos}

Sebanyak 6 famili yang terdiri dari 6 spesies makrozoobentos berhasil diidentifikasi dari tiga stasiun pengamatan, dimana secara keseluruhannya, makrozoobentos yang dominan dijumpai di kawasan reboisasi mangrove Kepulauan Seribu adalah gastropoda Littoraria scabra, brachyura Cardisoma carnifex dan bivalva Saccostrea cucullata (Tabel 1). Selain itu, gastropoda Atilia (Columbella) scripta dijumpai di Stasiun 2 dan 3, sedangkan brachyura Metopograpsus latifrons hanya ditemukan pada Stasiun 2. Begitu juga dengan gastropoda Nerita albicilla yang hanya dijumpai pada Stasiun 3. Hal ini mengindikasi bahwa brachyura $M$. latifrons dan gastropoda $N$. albicilla memiliki toleransi yang sangat sempit di kawasan reboisasi mangrove Kepulauan Seribu.

Tabel 1. Distribusi makrozoobentos di kawasan reboisasi mangrove Kepulauan Seribu

\begin{tabular}{cccccccc}
\hline \multirow{2}{*}{ Stasiun } & \multirow{2}{*}{ Plot } & \multicolumn{6}{c}{ Jenis Makrozoobentos } \\
\cline { 2 - 7 } & & AS & CC & LS & ML & NA & SC \\
\hline \multirow{2}{*}{1} & 1 & & + & + & & & + \\
& 2 & & & + & & & + \\
& 3 & & & + & & & + \\
\hline \multirow{2}{*}{2} & 1 & + & + & + & & & + \\
& 2 & & & + & + & & + \\
& 3 & & & + & & & + \\
\hline
\end{tabular}

Menurut Sasekumar (1974) dan Wells (1984) fauna makroinvertebrata yang biasanya mendominasi di daerah intertidal, baik 
itu dalam jumlah maupun biomassanya adalah kepiting brachyura dan gastropoda. Selanjutnya Ellison (2008) menyatakan bahwa kekayaan spesies kepiting brachyura dan gastropoda sangat paralel dengan kekayaan spesies mangrove dan kawasan hutannya, sehingga telah terbukti menjadi faktor kunci penjagaan fungsi dan layanan ekosistem mangrove (Cannicci et al., 2008; Lee, 2008). Mujiono (2009) menyatakan bahwa gastropoda yang dominan terdapat pada ekosistem mangrove terdiri dari Famili Littorinidae (misalnya L. scabra), Potamididae (misalnya Terebralia palustris, Telescopium telescopium), Muricidae, Onchinidae, Cerithiidae dan Ellobiidae. Selain itu, Macnae (1968) menambahkan bahwa komposisi spesies gastropoda juga tergantung pada posisi mangrove dalam hubungannya dengan pantai laut, misalnya di vegetasi mangrove zona daratan, gastropoda yang paling umum dijumpai adalah famili Ellobiidae, Assimineidae dan Neritidae, sementara hutan mangrove di pinggir laut, gastropoda yang sering dijumpai adalah famili Potamididae. Chen et al., (2007) menambahkan bahwa gastropoda dari keluarga Neritidae dan Ellobiidae lebih melimpah di hutan mangrove dewasa bila dibandingkan dengan hutan mangrove yang lebih muda (reboisasi).

Untuk komposisi makrozoobentos yang ditemukan di kawasan reboisasi mangrove Kepulauan Seribu, ditemukan bervariasi (Tabel 2). Hal ini diduga karena karakteristik lingkungannya yang berbeda-beda. Gastropoda L. scabra merupakan makrozoobentos yang tertinggi komposisinya $(92.23 \%)$, kemudian diikuti oleh brachyura $C$. carnifex (03.07\%), bivalva S. cucullata (02.04\%), gastropoda $A$. scripta (01.84\%) dan $N$. albicilla (00.20\%). Chen et al., (2007) menyatakan bahwa spesies dari famili Littoriinidae, Assimineidae dan Potamidae lebih representatif di hutan mangrove muda yang direhabilitasi. Selanjutnya Zvonareva et al., (2015) menyatakan bahwa komposisi spesies, keanekaragaman, biomassa serta kelimpahan invertebrata dapat mencerminkan status ekosistem mangrove dan dapat digunakan sebagai indikator perubahan, baik itu pada hutan mangrove alami maupun yang baru ditanam (reboisasi), kemudian Macintosh et al., (2002) menyatakan bahwa perbandingan fauna invertebrata dari berbagai jenis tegakan mangrove mengungkapkan bahwa keragaman vegetasi mangrove berkorelasi positif terhadap keragaman fauna yang terkait, dimana dalam indeks tegakan mangrove yang dewasa terdapat keanekaragaman fauna invertebrata yang lebih tinggi, sedangkan tegakan mangrove yang baru ditanam (hasil reboisasi) terdapat kelimpahan dan biomassa fauna invertebrata yang lebih rendah.

Tabel 2. Komposisi makrozoobentos di kawasan reboisasi mangrove Kepulauan Seribu

\begin{tabular}{|c|c|c|c|c|}
\hline No & Jenis & Genus & Famili & $\begin{array}{c}\text { Komposisi } \\
(\%)\end{array}$ \\
\hline \multicolumn{5}{|c|}{ Gastropoda } \\
\hline 1 & $\begin{array}{l}\text { Atilia (Columbella) } \\
\text { scripta }\end{array}$ & $\begin{array}{l}\text { Atilia } \\
\text { (Columbella) }\end{array}$ & Buccinidae & 01.84 \\
\hline
\end{tabular}




\begin{tabular}{|c|c|c|c|c|}
\hline No & Jenis & Genus & Famili & $\begin{array}{c}\text { Komposisi } \\
(\%)\end{array}$ \\
\hline 2 & Littoraria scabra & Littoraria & Littorinidae & 92.23 \\
\hline 3 & Nerita albicilla & Nerita & Neritidae & 00.20 \\
\hline \multicolumn{5}{|c|}{ Brachyura } \\
\hline 4 & $\begin{array}{l}\text { Cardisoma } \\
\text { carnifex }\end{array}$ & Cardisoma & Gecarcinidae & 03.07 \\
\hline 5 & $\begin{array}{l}\text { Metopograpsus } \\
\text { latifrons }\end{array}$ & Metopograpsus & Grapsidae & 00.61 \\
\hline \multicolumn{5}{|c|}{ Bivalva } \\
\hline 6 & $\begin{array}{l}\text { Saccostrea } \\
\text { cucullata }\end{array}$ & Saccostrea & Ostreidae & 02.04 \\
\hline
\end{tabular}

\section{Kepadatan Makrozoobentos}

Kepadatan makrozoobentos tiap stasiun di kawasan reboisasi mangrove Kepulauan Seribu tidak jauh berbeda (Tabel 3). Secara keseluruhan, kepadatan tertingginya adalah gastropoda $L$. scabra, baik itu di Stasiun 1, 2 maupun 3. Reid (1985) menyatakan bahwa sekelompok siput Littorinidae di pantai tropis secara khas ditemukan di pohon mangrove, dimana siput tersebut adalah Littorina scabra (Linne) dan $L$. angulifera (Lamarck) yang berasal dari Indo-Pasifik dan Atlantik. Hal yang sama juga dinyatakan oleh Alfaro (2007) dan Mujiono (2009) yaitu salah satu gastropoda yang dominan terdapat pada ekosistem mangrove adalah famili Littorinidae yakni L. scabra, kemudian di dalam tutupan mangrove, biasanya siput famili Littorinidae ditemukan di akar, batang maupun di dedaunan mangrove (Reid, 1985; 1986; Alvarez-Leon dan GarciaHansen, 2003).

\section{Karakteristik Lingkungan}

Karakteristik lingkungan yang diukur di kawasan reboisasi mangrove Kepulauan Seribu tidak begitu berbeda antar stasiunnya (Tabel 4). Hal ini karena letak geografis pulau (stasiun pengamatan) yang tidak terlalu jauh jaraknya. Selain itu, Tabel 4 juga memperlihatkan bahwa parameterparameter yang diukur tidak melebihi ambang batas baku mutu untuk biota laut, sehingga baik itu mangrove maupun makrozoobentosnya dapat mentolerir untuk tumbuh dan berkembang. Nobi et al., (2010) menyatakan bahwa kualitas air dan sedimen sangat penting untuk kelangsungan hidup dan kesejahteraan keanekaragaman hayati, terutama di daerah pesisir dan muara. Hal ini karena lingkungan intertidal mangrove merupakan lingkungan yang dinamis, baik itu secara fisik maupun geologis (Alongi, 2015), sehingga ekosistem mangrove menjadi rentan terhadap pengaruh lingkungan (Ghosh, 2011). 
Tabel 3. Kepadatan makrozoobentos di kawasan reboisasi mangrove Kepulauan Seribu

\begin{tabular}{|c|c|c|c|}
\hline Stasiun & Lokasi (Pulau) & Jenis Makrozoobentos & $\begin{array}{l}\text { Kepadatan } \\
\left.\text { (ind } / \mathrm{m}^{2}\right)\end{array}$ \\
\hline \multirow{4}{*}{1} & \multirow{4}{*}{ Pramuka } & Littoraria scabra & 06.33 \\
\hline & & Saccostrea cucullata & 00.20 \\
\hline & & Cardisoma carnifex & 00.40 \\
\hline & & Rata-Rata & 02.31 \\
\hline \multirow{6}{*}{2} & \multirow{6}{*}{ Panggang } & Littoraria scabra & 09.93 \\
\hline & & Atilia (Columbella) scripta & 00.53 \\
\hline & & Cardisoma carnifex & 00.27 \\
\hline & & Saccostrea cucullata & 00.40 \\
\hline & & Metopograpsus latifrons & 00.20 \\
\hline & & Rata-Rata & 02.27 \\
\hline \multirow{6}{*}{3} & \multirow{6}{*}{ Karya } & Littoraria scabra & 13.80 \\
\hline & & Cardisoma carnifex & 00.33 \\
\hline & & Atilia (Columbella) scripta & 00.07 \\
\hline & & Saccostrea cucullata & 00.07 \\
\hline & & Nerita albicilla & 00.07 \\
\hline & & Rata-Rata & 02.89 \\
\hline
\end{tabular}

Tabel 4. Karakteristik lingkungan di kawasan reboisasi mangrove Kepulauan Seribu

\begin{tabular}{ccccc}
\hline \multirow{2}{*}{ Stasiun } & \multicolumn{4}{c}{ Kualitas Air } \\
\cline { 2 - 5 } & Suhu ( $\left.{ }^{\circ} \mathbf{C}\right)$ & Salinitas (\%o) & pH & ${ }^{*}$ DO \\
\hline 1 & 32 & 30 & 7.7 & ${ }^{\mathrm{b}} 6.7$ \\
2 & 32 & 33 & 6.6 & ${ }^{\mathrm{c}} 7.0$ \\
3 & 30 & 31 & 7.0 & ${ }^{\mathrm{c}} 6.0$ \\
${ }^{\mathrm{a}}$ Baku mutu & $28-32$ & s/d 34 & $7-8.5$ & $>5$ \\
\hline${ }^{*}$ Data
\end{tabular}

*Data sekunder; ${ }^{a} \mathrm{MNLH}$ (2004); ${ }^{\mathrm{b}}$ Faiqoh et al., (2015); ${ }^{\mathrm{C}}$ Riani et al., (2017)

Saintilan et al., (2014) menyatakan bahwa suhu merupakan faktor pembatas utama bagi mangrove yang menempati kisaran garis lintang, dimana suhu memberikan penjelasan secara korelatif terhadap penyebaran mangrove (Osland et al., 2013). Selanjutnya Nguyen et al., (2015) menyatakan bahwa salinitas adalah salah satu ciri lingkungan yang mendefinisikan habitat mangrove, apakah berkisar antara air tawar ataupun hypersaline. Sementara Rukminasari et al., (2014) menyatakan bahwa $\mathrm{pH}$ air laut permukaan Indonesia pada umumnya berkisar antara 6 -8.5 .

\section{Pengaruh Karakteristik Lingkungan Terhadap Makrozoobentos}

Gambar 2 memperlihatkan bahwa semakin rendah konsentrasi salinitas dan DO, maka kepadatan makrozoobentos di kawasan reboisasi 
mangrove Kepulauan seribu semakin tinggi, kemudian untuk parameter $\mathrm{pH}$ memperlihatkan bahwa semakin tinggi konsentrasi $\mathrm{pH}$, maka kepadatan makrozoobentosnya akan semakin menurun. Menurut Rukminasari et al., (2014) berubahnya nilai pH akan menimbulkan perubahan dan ketidakseimbangan kadar $\mathrm{CO}_{2}$ dan dapat membahayakan kehidupan biota laut. Selanjutnya, Hamzah dan Setiawan (2010) menyatakan bahwa faktor yang mempengaruhi rendahnya nilai $\mathrm{pH}$ di suatu kawasan adalah proses reaksi reduksi dan oksidasi yang terjadi pada sedimen, dimana organisme pengurai melepaskan asam saat melakukan akumulasi dekomposisi bahan organik (Gopinath et al., 2010), kemudian Supriyantini et al., (2017) menyatakan bahwa rendahnya konsentrasi oksigen terlarut (DO) disebabkan karena adanya proses oksidasi yang menggunakan sejumlah besar oksigen yang menghasilkan nitrogen ammonia $\left(\mathrm{N}-\mathrm{NH}_{4}\right)$.
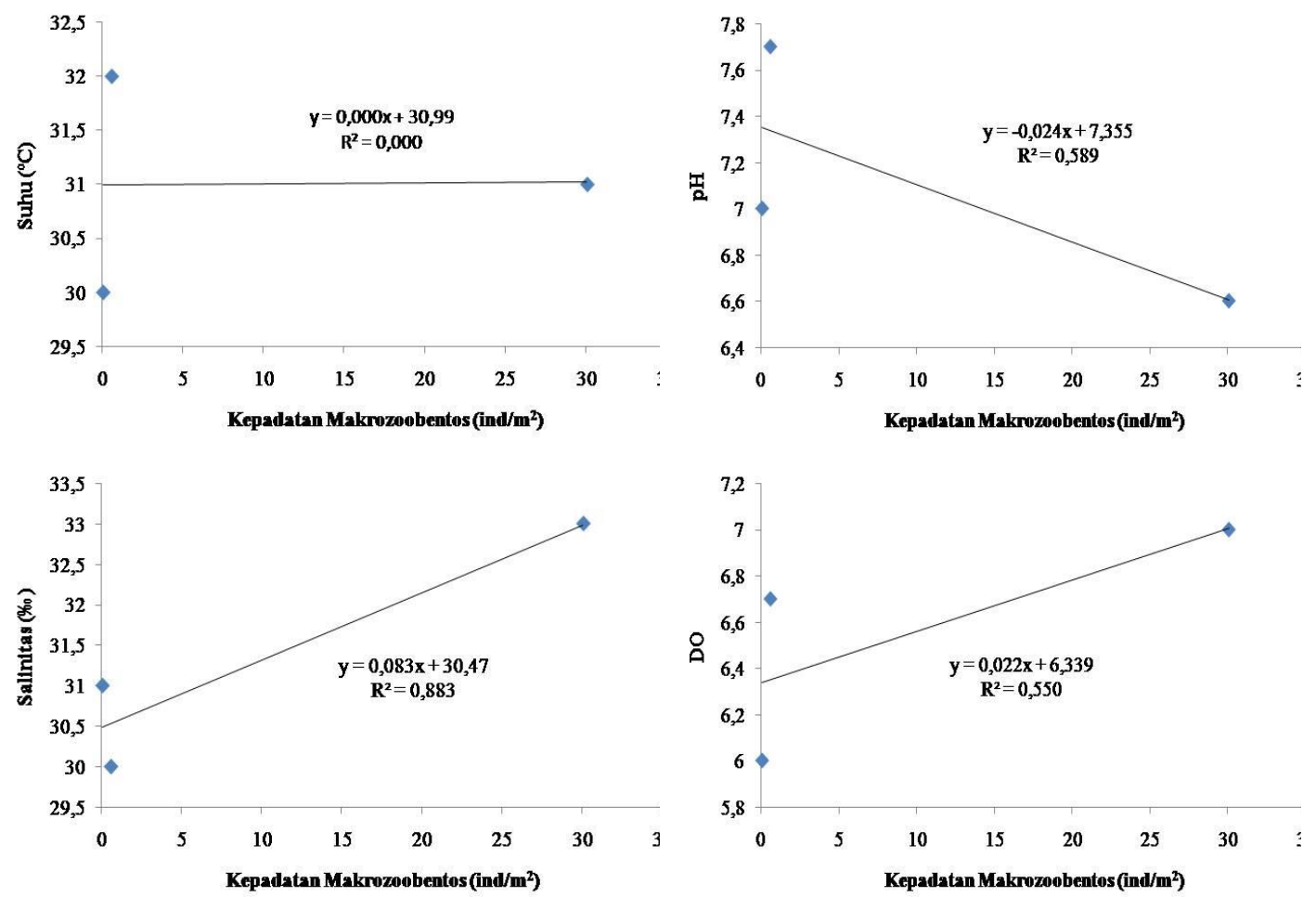

Gambar 2. Pengaruh karakteristik lingkungan terhadap makrozoobentos di kawasan reboisasi mangrove Kepulauan Seribu

Selain itu, Gambar 2 juga memperlihatkan bahwa koefisien determinasi yang diperoleh dari korelasi karakteristik lingkungan dengan kepadatan makrozoobentos di kawasan reboisasi mangrove Kepulauan Seribu sangat bervariasi. Hal ini terlihat dari nilai koefisien korelasi antara kepadatan makrozoobentos dengan suhu sebesar 0.000 , kepadatan makrozoobentos dengan $\mathrm{pH}$ sebesar 0.767 , kepadatan makrozoobentos dengan salinitas sebesar 0.940 dan kepadatan makrozoobentos dengan DO sebesar 0.742 , sehingga pengaruh karakteristik lingkungan dengan 
kepadatan makrozoobentos di kawasan reboisasi mangrove Kepulauan Seribu mengindikasikan tingginya kepadatan makrozoobentos dapat dijelaskan oleh faktor suhu sebesar $00.00 \%$, pH $58.90 \%$, salinitas $88.30 \%$ serta DO $55.00 \%$ dan sisanya dijelaskan oleh faktor-faktor lain (suhu $100 \%$, pH $41.10 \%$, salinitas $11.70 \%$ dan DO $45.00 \%)$.

\section{KESIMPULAN}

Kajian ini mengindentifikasi 6 famili dan 6 spesies makrozoobentos di kawasan reboisasi mangrove Kepulauan Seribu. Komposisi dan kepadatan spesies tertingginya adalah L. scabra, kemudian karakteristik lingkungan yang diukur tidak begitu berbeda antar stasiun dan juga tidak melebihi ambang batas baku mutu. Selanjutnya pengaruh karakteristik lingkungan terhadap makrozoobentos memperlihatkan semakin rendah konsentrasi salinitas dan DO, maka kepadatan makrozoobentosnya semakin tinggi, sedangkan pengaruh $\mathrm{pH}$ kebalikannya yaitu semakin tinggi konsentrasi $\mathrm{pH}$ perairan, maka kepadatan makrozoobentosnya semakin menurun, kemudian parameter suhu dengan kepadatan makrozoobentos tidak memiliki pengaruh antara keduanya.

\section{UCAPAN TERIMA KASIH}

Ucapan terimakasih disampaikan kepada pihak Taman Nasional Kepulauan Seribu (TNKS) yang telah menyediakan fasilitas penginapan. Selain itu, ucapan terimakasih juga disampaikan kepada masyarakat Pulau Paramuka yang telah membantu saat pengambilan sampel di lapangan.

\section{DAFTAR PUSTAKA}

Aboudha PAW, Kairo JG. 2001. Human-induced stresses on mangrove swamps along the Kenyan coast. Hydrobiologia. 458(1-3): 255 - 265.

Alfaro AC. 2007. Migration and trail affinity of snails, Littoraria scabra, on mangrove trees of Nananu-i-ra, Fiji Islands. Marine and Freshwater Behaviour and Physiology. 40(4): $247-255$.

Alongi DM. 2008. Mangrove forests: Resilience, protection from tsunamis, and responses to global climate change. Estuarine, Coastal and Shelf Science. 76(1): $1-13$.

Alongi DM. 2013. Cycling and global fluxes of nitrogen in mangroves. Global Environmental Research. 17: 173 - 182.

Alongi DM. 2015. The impact of climate change on mangrove forests. Current Climate Change Reports. 1(1): $30-39$. 
Alvarez-Leon R, Garcia-Hansen I. 2003. Biodiversity associated with mangroves in Colombia. ISME/GLOMIS Electronic Journal. 3(1): 1 2.

Bandaranayake WM. 1998. Traditional and medicinal uses of mangroves. Mangroves and Salt Marshes. 2(3): 133 - 148.

Barbier EB. 2006. Natural barriers to natural disasters: Replanting mangroves after the tsunami. Frontiers in Ecology and The Environment. 4(3): $124-131$.

Benzeev R, Hutchinson N, Friess DA. 2017. Quantifying fisheries ecosystem services of mangroves and tropical artificial urban shorelines. Hydrobiologia. 803(1): 225 - 237.

Bosire JO, Dahdouh-Guebas F, Walton M, Bcrona BI, Lewis III RR, Field C, Kairo JG, Koedam N. 2008. Functionality of restored mangroves: A review. Aquatic Botany. 89(2): $251-259$.

Brower JE, Zar JH. 1984. Field and Laboratory Methods for General Ecology Second Edition. Dubuque, IA : W.C. Brown Publishers.

Cannicci S, Burrows D, Fratini S, Smith TJ, Offenberg J, Dahdouh-Guebas F. 2008. Faunal impact on vegetation structure and ecosystem function in mangrove forests: A review. Aquatic Botany. 89(2): 186 200.

Chen G, Ye Y, Lu C. 2007. Changes of macro-benthic faunal community with stand age of rehabilitated Kandelia candel mangrove in Jiulongjiang Estuary, China. Ecological Engineering. 31(3): 215 224.

Chong VC. 2007. Mangroves-fisheries linkages - The Malaysian perspective. Bulletin of Marine Science. 80(3): 755 - 772.

Das S, Vincent JR. 2009. Mangroves protected villages and reduced death toll during Indian super cyclone. Proceedings of the National Academy of Sciences. 106(18): $7357-7360$.

Donato DC, Kauffman JB, Murdiyarso D, Kurnianto S, Stidham M, \& Kanninen M. 2011. Mangroves among the most carbon-rich forests in the tropics. Nature Geoscience. 4: 293 - 297.

Elliott M, Mander L, Mazik K, Simenstad C, Valesini F, Whitfield A, Wolanski E. 2016. Ecoengineering with Ecohydrology: Successes and failures in estuarine restoration. Estuarine, Coastal and Shelf Science. 176: $12-35$. 
Ellison AM. 2008. Managing mangroves with benthic biodiversity in mind: Moving beyond roving banditry. Sea Research. 59(1-2): 2 - 15.

Ernanto R, Agustriani F, Aryawati R. 2010. Struktur komunitas gastropoda pada ekosistem mangrove di muara Sungai Batang Ogan Komering llir Sumatera Selatan. Maspari. 1: 73 - 78.

Faiqoh E, Ayu IP, Subhan B, Syamsuni YF, Anggoro AW, Sembiring A. 2015. Variasi geografik kelimpahan zooplankton di perairan terganggu, Kepulauan Seribu, Indonesia. Marine and Aquatic Sciences. 1: $19-22$.

[FAO] Food and Agriculture Organization. 2007. The World's Mangroves 1980 - 2005: A Thematic Study Prepared in The Frameworkof The Global Forest Resources Assessment 2005. Roma, Itali.

Field CD. 1999. Mangrove rehabilitation: Choice and necessity. Hydrobiologia. 413(0): $47-52$.

Friess DA, Webb EL. 2013. Variability in mangrove change estimates and implications for the assessment of ecosystem service provision. Global Ecology and Biogeography. 23(7): 715 - 725.

Ghosh D. 2011. Mangroves: The most fragile forest ecosystem. Resonance. 16(1): $47-60$.

Gillis LG, Belshe EF, Narayan GR. 2017. Deforested mangroves affect the potential for carbon linkages between connected ecosystems. Estuaries and Coasts. 40(4): 1207 - 1213.

Giri C, Zhu Z, Tieszen LL, Singh A, Gillette S, Kelmelis JA. 2008. Mangrove forest distributions and dynamics (1975-2005) of the tsunami-affected region of Asia. Biogeography. 35(3): 519 - 528.

Goecke SD, Carstenn SM. 2017. Fish communities and juvenile habitat associated with non-native Rhizophora mangle L. in Hawai'i. Hydrobiologia. 803(1): $209-224$.

Gopinath A, Nair SM, Kumar NC, Jayalakshmi KV, Pamalal D. 2010. A baseline study of trace metals in a coral reef sedimentary environment, Lakshadweep Archipelago. Environmental Earth Sciences. 59(6): $1245-1266$.

Hamzah F, Setiawan A. 2010. Akumulasi logam berat $\mathrm{Pb}, \mathrm{Cu}$, dan $\mathrm{Zn}$ di hutan mangrove Muara Angke, Jakarta Utara. IImu dan Teknologi Kelautan Tropis. 2(2): $41-52$. 
Hasby M, Thamrin, Sukendi. 2014. Keberlanjutan biota Sungai Sail Kota Pekanbaru (studi kasus distribusi dan kelimpahan makrozoobenthos). Dinamika Pertanian. 29(3): 295 - 306.

Kamal S, Warnken J, Bakhtiyari M, Lee SY. 2017. Sediment distribution in shallow estuaries at fine scale: In situ evidence of the effects of three-dimensional structural complexity of mangrove pneumatophores. Hydrobiologia. 803(1): $121-132$.

Kelleway JJ, Saintilan N, Macreadie PI, Skilbeck CG, Zawadzki A, Ralph PJ. 2016. Seventy years of continuous encroachment substantially increases 'blue carbon' capacity as mangroves replace intertidal salt marshes. Global Change Biology. 22(3): 1097 - 1109.

Kodikara KAS, Mukherjee N, Jayatissa LP, Dahdouh-Guebas F, Koedam N. 2017. Have mangrove restoration projects worked? An in-depth study in Sri Lanka. Restoration Ecology. 25(5): 705 - 716.

Krebs CJ. 1989. Ecological Methodology. New York: University of British Columbia, Harper Collins Publishers.

Lee SY. 2008. Mangrove macrobenthos: Assemblages, services and linkages. Sea Research. 59(1-2): $16-29$.

Macintosh DJ, Ashtona EC, Havanon S. 2002. Mangrove rehabilitation and intertidal biodiversity: A study in the Ranong Mangrove. Estuarine, Coastal and Shelf Science. 55(3): 331 - 345.

Macnae W. 1968. A general account of the fauna and flora of mangrove swamps and forests in the Indo-West-Pacific region. Advances in Marine Biology. 6: 73 - 270.

Mayaux P, Holmgren P, Achard F, Eva H, Stibig H, Branthomme A. 2005. Tropical forest cover change in the 1990s and options for future monitoring. Philosophical Transactions of The Royal Society $B$ Biological Sciences. 360(1454): $373-384$.

[MNLH] Menteri Negara Lingkungan Hidup. 2004. Keputusan Menteri Negara Lingkungan Hidup tentang Baku Mutu Air Laut Nomor 51. Jakarta, Indonesia.

Mujiono N. 2009. Mudwhelks (Gastropoda: Potamididae) from mangroves of Ujung Kulon National Park, Banten. Biologi. 13(2): 51 - 56.

Mushthofa A, Muskananfola MR, Rudiyanti S. 2014. Analisis struktur komunitas makrozoobenthos sebagai bioindikator kualitas perairan Sungai Wedung Kabupaten Demak. Management of Aquatic Resources. 3(1): $81-88$. 
Mustofa A. 2018. Pengaruh total padatan tersuspensi terhadap biodiversitas makrozoobentos di pantai Telukawur Kabupaten Jepara. Disprotek. 9(1): $37-45$.

Nguyen HT, Stanton DE, Schmitz N, Farquhar GD, Ball MC. 2015. Growth responses of the mangrove Avicennia marina to salinity: Development and function of shoot hydraulic systems require saline conditions. Annals of Botany. 115(3): 397 - 407.

Nobi EP, Dilipan E, Thangaradjou T, Sivakumar K, Kannan L. 2010. Geochemical and geo-statistical assessment of heavy metal concentration in the sediments of different coastal ecosystems of Andaman Islands, India. Estuarine, Coastal and Shelf Science. 87(2): $253-264$.

Odum EP. 1971. Fundamentals of Ecology 3rd Edition. W. B. Saunders Co. Philadelphia.

Osland MJ, Enwright N, Day RH, Doyle TW. 2013. Winter climate change and coastal wetland foundation species: Salt marshes vs. mangrove forests in the Southeastern United States. Global Change Biology. 19(5): $1482-1494$.

Pagliosaa PR, Oortman MS, Rovai AS, Soriano-Sierra EJ. 2016. Is mangrove planting insufficient for benthic macrofaunal recoverywhen environmental stress is persistent?. Ecological Engineering. 95: 290 $-301$.

Pamuji A, Muskananfola MR, A'in C. 2015. Pengaruh sedimentasi terhadap kelimpahan makrozoobenthos di muara Sungai Betahwalang Kabupaten Demak. Saintek Perikanan. 10(2): 129 135.

Polidoro BA, Carpenter KE, Collins L, Duke NC, Ellison AM, Ellison JC, Farnsworth EJ, Fernando ES, Kathiresan K, Koedam NE, Livingstone SR, Miyagi T, Moore GE, Nam VN, Ong JE, Primavera JH, Salmo SG, Sanciangco JC, Sukardjo S, Wang Y, Yong JWH. 2010. The loss of species: Mangrove extinction risk and geographic areas of global concern. Plos One. 5(4): $1-10$.

Reid DG. 1985. Habitat and zonation patterns of Littoraria species (Gastropoda: Littorinidae) in Indo- Pacific mangrove forests. Biological Journal of The Linnean Society. 26(1): 39 - 68.

Reid DG. 1986. The Littorinid Molluscs of Mangrove Forests in the IndoPacific Region: The Genus Littoraria. London, Inggris. 
Riani E, Johari HS, Cordova MR. 2017. Bioakumulasi logam berat kadmium dan timbal pada Kerang Kapak-Kapak di Kepulauan Seribu. Pengolahan Hasil Perikanan Indonesia. 20(1): 131 - 142.

Rukminasari N, Nadiarti, Awaluddin K. 2014. Pengaruh derajat keasaman $(\mathrm{pH})$ air laut terhadap konsentrasi kalsium dan laju pertumbuhan Halimeda sp. Torani. 24(1): 28 - 34.

Saintilan N, Wilson N, Rogers K, Rajkaran A, Krauss KW. 2014. Mangrove expansion and salt marsh decline at mangrove poleward limits. Global Change Biology. 20(1): 147 - 157.

Salmo SG, Tibbetts I, Duke NC. 2017. Colonization and shift of mollusc assemblages as a restoration indicator in planted mangroves in the Philippines. Biodiversity and Conservation. 26(4): 865 - 881.

Sasekumar A. 1974. Distribution of macrofauna on a Malayan mangrove shore. Animal Ecology. 43(1): 51 - 69.

Sheng YP, Zou R. 2017. Assessing the role of mangrove forest in reducing coastal inundation during major hurricanes. Hydrobiologia. 803(1): 87 $-103$.

Siikamaki J, Sanchirico JN, Jardine SL. 2012. Global economic potential for reducing carbon dioxide emissions from mangrove loss. Proceedings of the National Academy of Sciences. 109(36): 14369 14374.

Southwood TRE. 1978. Ecological Methods. London, Inggris.

Supriyantini E, Nuraini RAT, Fadmawati AP. 2017. Studi kandungan bahan organik pada beberapa muara sungai di kawasan ekosistem mangrove, di wilayah pesisir pantai Utara Kota Semarang, Jawa Tengah. Buletin Oseanografi Marina. 6(1): 29 - 38.

Suzuki T, Zijlema M, Burger B, Meijer MC, Narayan S. 2011. Wave dissipation by vegetation with layer schematization in SWAN. Coastal Engineering. 59(1): $64-71$.

Wahyuningrum ES, Muskananfola MR, Suryanto A. 2016. Hubungan tekstur sedimen, bahan organik dengan kelimpahan biota makrozoobentos di perairan Delta Wulan, Kabupaten Demak. Management of Aquatic Resources. 5(1): 46 - 51.

Wells FE. 1984. Comparative distribution of macromolluscs and macrocrustaceans in a North-Western Australian mangrove system. Australian Journal of Marine and Freshwater Research. 35(5): 591 596. 
Wolanski E, Spagnol S, Thomas S, Moore K, Alongi DM, Trott L, Davidson A. 2000. Modelling and visualizing the fate of shrimp pond effluent in a mangrove-fringed tidal creek. Estuarine, Coastal and Shelf Science. 50(1): $85-97$.

Yando ES, Osland MJ, Willis JM, Day RH, Krauss KW, Hester MW. 2016. Salt marsh-mangrove ecotones: Using structural gradients to investigate the effects of woody plant encroachment on plant-soil interactions and ecosystem carbon pools. Ecology. 104(4): 1020 1031.

Zainuri AM, Takwanto A, Syarifuddin A. 2017. Konservasi ekologi hutan mangrove di Kecamatan Mayangan Kota Probolinggo. Dedikasi. 14: $1-7$.

Zvonareva S, Kantor Y, Li X, Britayev T. 2015. Long-term monitoring of Gastropoda (Mollusca) fauna in planted mangroves in central Vietnam. Zoological Studies. 54(39): 1- 16. 